\title{
EXPRESSION OF LHC GENES AND THEIR RELATION TO PHOTO- OXIDATIVE STRESS TOLERANCE IN Solanum lycopersicum L. AND Solanum chilense (Dunal) Reiche
}

\author{
Javier Chilian ${ }^{1 *}$, Isabel Verdugo ${ }^{1}$, Fernando Poblete ${ }^{1}$, Simón Ruiz-Lara $^{1}$, José A. Casaretto ${ }^{1}$, \\ and Enrique González ${ }^{1}$
}

\begin{abstract}
Simultaneous exposition to low temperature and high light radiation cause photoinhibition of photosynthetic apparatus, affecting the productivity and geographical distribution of agricultural crops. In several Solanaceous species, tolerance to low temperature stress in combination with high light has been associated with some stimulation in non-photochemical quenching (NPQ), which involved reorganization in light-harvesting complex (LHC) proteins. To study photosynthetic performance in Solanum lycopersicum L. and S. chilense (Dunal) Reiche, and to investigate transcriptional regulation of genes encoding LHC proteins and their involvement in the NPQ, plants of both species were exposed to low temperature $\left(4{ }^{\circ} \mathrm{C}\right)$ and high light radiation $\left(1300 \mu \mathrm{mol} \mathrm{m} \mathrm{m}^{-2} \mathrm{~s}^{-1}\right)$. Lipid peroxidation, photochemical efficiency, and changes in xanthophyll cycle pigments were measured. The results presented here indicate that $S$. chilense showed higher tolerance to photoinhibition than S. lycopersicum under low-temperature and high light conditions, increasing light-energy consumption in photochemical processes by increasing photosynthetic capacity as indicated by photochemical quenching $(\mathrm{qP})$ and relative electron transport rate (ETR) parameters. The contribution of light-harvesting chlorophyll a/b binding (LHC) protein was not related to dissipate excess excitation energy as heat (NPQ), but rather with the antioxidant function attributable to zeaxanthin as indicated by the amount of peroxidized lipids in S. chilense. We suggest that the differential expression of Lhcal transcripts, with zeaxanthin binding sites could contribute to the greater tolerance of $S$. chilense to photoxidative stress.
\end{abstract}

Key words: Lipid-peroxidation, photoinhibition, photochemical quenching, zeaxanthin.

$\mathrm{L}$ ow temperature is one of the most important factors affecting the productivity and geographical distribution of agricultural crops (Allen and Ort, 2001). Simultaneous exposition to low temperature and high light radiation cause photoinhibition of photosynthetic apparatus (Long et al., 1994). Low temperature generally reduces reaction rates and therefore can limit the sinks - $\mathrm{CO}_{2}$ fixation and photorespiration - for the absorbed excitation energy (light) (Foyer, 2002; Karpinski et al., 2002). The absorbed light that exceeds the photosynthetic capacities can lead to increased production of reactive oxygen species (ROS) (Ledford and Niyogi, 2005) causing photo-oxidative damage to lipids, proteins, nucleic acids and photosynthetic pigments (Mittler et al., 2004; Møller et al., 2007).

The xanthophyll cycle can play a crucial role in protecting plants from photo-oxidative damage (DemmigAdams and Adams, 1996; Niyogi, 1999). In this cycle,

${ }^{1}$ Universidad de Talca, Instituto de Biología Vegetal y Biotecnología, 2 Norte $\mathrm{N}^{\mathrm{o}} 685$, Talca, Chile. ${ }^{*}$ Corresponding author (jchilian@inia.cl). Received: 14 January 2011.

Accepted: 29 September 2011. the diepoxide xanthophyll violaxanthin is converted via the intermediate antheraxanthin to the epoxide-free zeaxanthin (Yamamoto, 1979). Once low light (dark) conditions are restored, zeaxanthin is epoxidized back to violaxanthin. Zeaxanthin has a role in the dissipation of excess excitation energy as heat by a process termed non-photochemical quenching (NPQ) (Holt et al., 2004). NPQ is important for the protection of the photosynthetic apparatus against photo-damage reducing the energy delivery to the photosystem II (PSII) reaction centre and minimizing the generation of reactive oxygen species (ROS) (Horton et al., 1994; Muller et al., 2001; Havaux et al., 2004). On the other hand, zeaxanthin also appears to have a role in tolerance to photo-oxidative stress protecting membranes against lipid peroxidation by a different mechanism from NPQ (Lichtenthaler and Schnidler, 1992). Carotenoids are essential components of light-harvesting chlorophyll (chl) a/b binding (LHC) protein (Wehner et al., 2004) and therefore the chemical transformation of the xanthophyll cycle induces a reorganization in light-harvesting complex (LHC) proteins (i.e. from a state of efficient light harvesting to a state of high thermal energy dissipation; Nelson and Yocum, 
2006). This change is related to differential expression of genes encoding LHC proteins (Demmig-Adams et al., 1996; Savitch et al., 2002; Ensminger et al., 2004). It was proposed that PsbS, a distant member of the LHC family, might play a protective role within the thylakoids under photoinhibitory conditions, with a central role in NPQ (Li et al., 2000). A similar non-light harvesting function was proposed for ELIP proteins, another distant relative of LHC family that accumulates when the expression of Lhc proteins is downregulated and are therefore thought to play a role in photoprotection, either via a transient binding of free chlorophyll to avoid the transference to oxygen and/or in zeaxanthin-dependent photo-protection (Montané and Kloppstech, 2000; Adamska, 2000; Andersson et al., 2003; Hutin et al., 2003). Interestingly, the photosystem I (PSI) antenna complex is made up of proteins whose primary function is to collect energy. When plants are exposed to conditions that may generate photo-oxidative damage, these proteins assume a conformation able to dissipate the excess energy excitation as heat (Morosinotto et al., 2002; Ben-Shem et al., 2004).

In several Solanaceous species, tolerance to low temperature stress in combination with high light has been reported to be associated with some stimulation in NPQ (Venema et al., 1999; Rorat et al., 2001), however, there are few studies relating such tolerance to gene expression. In this context, the native species Solanum chilense (Dunal) Reiche, with proven tolerance to several abiotic stress conditions (Maldonado et al., 2003; Venema et al., 2005; Tapia, 2005; Yáñez et al., 2009) becomes as potential germplasm source.

Therefore, in an effort to compare molecular mechanisms underlying gene regulation related to lowtemperature tolerance in wild and cultivated tomatoes the aim of this study was evaluate the transcriptional regulation of genes encoding LHC proteins and their involvement in the NPQ in S. lycopersicum and S. chilense under simultaneous exposition to low temperature and high light radiation.

\section{MATERIALS AND METHODS}

\section{Plant material and growth conditions}

Solanum chilense fruits were collected in the Atacama Desert of Chile, at ca. 2400 m.a.s.1. (18'28' S, 6945' W). Seeds were extracted from fruits, washed and sterilized before sowing them in pots with a soil:perlite mix $(1: 1)$. Solanum lycopersicum cv. Moneymaker seeds were also germinated in pots with the same soil:perlite mixture. All plants were irrigated with a mineral nutrient solution (Murashige and Skoog, 1962, $1 \mathrm{~g} \mathrm{~L}^{-1}$ ) and grown for 10 wk in growth chambers in a 16:8 $\mathrm{h}$ photoperiod regime at 20-22 ${ }^{\circ} \mathrm{C}$.

\section{Low temperature and high-light treatment}

Plants were transferred at the beginning of photoperiod to a climate room at a constant temperature of $4{ }^{\circ} \mathrm{C}$ and light intensity of $1300 \mu \mathrm{mol} \mathrm{m}{ }^{-2} \mathrm{~s}^{-1}$ for $4 \mathrm{~h}$. Light was provided by two high pressure sodium lights (OSRAM SON-T 400 W lamps). To prevent heating of the samples, light was filtered through a water layer of $10 \mathrm{~cm}$.

\section{Measurements of chlorophyll fluorescence parameters}

Fluorescence signals were generated by a pulseamplitude modulated fluorimeter (FMS 2, Hansatech Instruments Ltd., Norfolk, UK). Attached leaves of both species were dark adapted for 20 min with leafclips with a mobile shutter plate. The fiber-optic and its adapter were fixed to a ring located over the clip at about $10 \mathrm{~mm}$ from the sample and different light pulses (see below) were applied following the standard routines programmed within the equipment. Signal recordings and calculations were performed using the data analyses and control software provided by the manufacturers (Hansatech Instruments Ltd., Norfolk, UK). According to the terminology of van Kooten and Snel (1990), minimal or initial fluorescence (Fo) was determined applying a weak modulated light $(0.4 \mu \mathrm{mol}$ photons $\mathrm{m}^{-2} \mathrm{~s}^{-1}$ ) and maximal fluorescence (Fm) was induced in dark adapted leaves by a short pulse $(0.8 \mathrm{~s})$ of saturating light (around $9000 \mu \mathrm{mol}$ photons $\mathrm{m}^{-2} \mathrm{~s}^{-1}$ ). Shortly after relaxation of Fm actinic light was turned on (600 $\mu \mathrm{mol}$ photons $\mathrm{m}^{-2} \mathrm{~s}^{-1}$ ). This light intensity corresponded to the mean obtained by light response curves for both species. Both species were saturated at this light intensity, but they were not photoinhibited. Then, the same saturating pulse was applied every $20 \mathrm{~s}$ in order to obtain Fm', the steady state value of fluorescence immediately prior to the flash, corresponded to Fs. Finally, Fo' was measured after turning the actinic light off and applying a $2 \mathrm{~s}$ far red light pulse. Definitions of fluorescence parameters (qP, NPQ, Fv/Fm, and $\Phi$ PSII) were used as described by van Kooten and Snel (1990). Fv/Fm and $\Phi P S I I=(F m$ ' - Fs $) / F m$ ' are indicators of the maximum and effective quantum yield of the PSII (Genty et al., 1989) respectively. Photochemical quenching (qP) was calculated as: $\mathrm{qP}=(\mathrm{Fm}$ ' - Fs $) /(\mathrm{Fm}$ ' - Fo' $)$, with Fm' being the maximal fluorescence in light adapted leaves, and Fs the steady state fluorescence yield. Non photochemical quenching was calculated as: NPQ $=(\mathrm{Fm}-\mathrm{Fm}$ ' $) / \mathrm{Fm}$ '. Relative electron transport rate was calculated as: ETR $=\mathrm{PPFD} \times 0.5 \times \Phi$ PSII $\times 0.84$.

\section{Photosynthetic pigment determination}

Leaf discs (13 mm diameter) were punched from leaves of plants which were grown at optimal or low temperature and high-light treatment conditions. Leaf discs were immersed in liquid $\mathrm{N}_{2}$ and stored at $-80{ }^{\circ} \mathrm{C}$ until use. The frozen leaf discs were powdered with liquid $\mathrm{N}_{2}$ and pigments were extracted with $700 \mu \mathrm{L}$ ice-cold acetone. After centrifugation $\left(4{ }^{\circ} \mathrm{C}\right.$ for $6 \mathrm{~min}$ at $5000 \mathrm{~g}$ ), the supernatant fractions were filtered through a $0.45 \mu \mathrm{m}$ 
syringe filter and stored at $-20{ }^{\circ} \mathrm{C}$ until use. The HPLC system was a Hewlett Packard 1100 liquid chromatograph (Agilent Technologies Inc., San José, California, USA). For analysis of xanthophylls, $20 \mu \mathrm{L}$ of extract were injected in a C18 reversed phase HPLC column $(250 \times$ $4.60 \mathrm{~mm}, 5 \mu \mathrm{m}$ particle size). Violaxanthin, anteraxanthin and zeaxanthin were separated according to Gilmore and Yamamoto (1991) and were identified by their retention times relative to known standards. Concentrations were calculated as based on calibration-curves create with the standards. The standards were purified in our laboratory by thin layer chromatography.

\section{Lipid peroxidation}

The malondialdehyde (MDA) assay for estimating lipid peroxidation was carried out on leaf tissue as described in Hodges et al. (1999) with minor modifications. Briefly, leaf discs $\left(1.33 \mathrm{~cm}^{2}\right)$ were ground and suspended in 1 $\mathrm{mL}$ of ice cold $5 \% \mathrm{w} / \mathrm{v}$ tricloracetic acid (TCA) and centrifuged at $4000 \mathrm{~g}$ for $10 \mathrm{~min}$. Then, $0.5 \mathrm{~mL}$ of the supernatant was mixed with an equal volume of $0.67 \%$ $\mathrm{w} / \mathrm{v}$ thiobarbituric acid (TBA), incubated at $100{ }^{\circ} \mathrm{C}$ for 20 min and chilled immediately. An absorbance difference of $532 \mathrm{~nm}$ and $600 \mathrm{~nm}$ was measured in a spectrophotometer (UV-1601, Shimadzu, Japan). Extinction coefficient used for MDA determination was $155 \mathrm{mM}^{-1} \mathrm{~cm}^{-1}$.

\section{cDNA isolation from Solanum species}

The cDNAs encoding PsbS,Lhcal, and Elip were amplified by RT-PCR with RNA extracted from $S$. chilense and $S$. lycopersicum leaves as described below. Primers used were designed based on nucleotide sequences available in the National Center for Biotechnology Information (NCBI)/GenBank Database. Primers used to amplify the homologous gene in each species was PsbSf 5'-ATG GCT CAA ACA ATG TTG TTA ACA-3', and PsbSr 5'CCA ATC ATA GCA ACA CGG CCA AC-3', for PsbS (accession number U04336), primers Lhcalf 5'-GAG GCA TTG GGC TTA GGT AAT TGG G-3' and Lhca1r 5'-TCC CCC AAT GTT GTT GTG CCA TGG G-3' for Lhca1 (accession number J03558) and primers Elipf 5'-ATG GCT TCA CTC TCA TCT TC-3' and Elipr 5'AGA GAG GAA TAT CAA GGC C-3' for Elip (primers were designed by homology with Arabidopsis thaliana accession number AAM62880.1). For each species, three independent amplification products were cloned into the pGEMT-Easy vector (Promega) and sequenced. Nucleotide sequences were then compared to those described for tomato in the gene index of National Center for Biotechnology Information (2010). Deduced amino acid sequences were aligned using the ClustalW tool and identity between the proteins was calculated with BioEdit program (BioEdit, 2010).

\section{Gene expression analysis}

For Lhcal, PsbS, and Elip expression analyses, three independent total RNA extractions (biological replicates) were made from leaves (100 mg) of 10 to 12 -wk-old plants using the SV Total RNA Isolation System (Promega, Madison, Wisconsin, USA) following the manufacturer's instructions. Leaves were harvested, flash-frozen in liquid nitrogen and kept at $-80{ }^{\circ} \mathrm{C}$. Total RNA integrity was verified by formaldehyde agarose gel electrophoresis and their purity by $\mathrm{OD}_{260} / \mathrm{OD}_{280} \mathrm{~nm}$ absorbance ratio > 1.95. Following DNase treatment of total RNA, firststrand cDNA synthesis was carried out from $2 \mu \mathrm{g}$ of total RNA for each sample using oligo(dT) according to the manufacturer's instructions (Thermoscript RTPCR System, Invitrogen, Carlsbad, California, USA). Transcript levels of genes were measured by quantitative PCR (qRT-PCR) using a DNA Engine Opticon 2 Cycler System (MJ Research, USA). All reactions were performed using the Brilliant SYBR Green Master Mix (Stratagene, USA) according to the procedure described by the manufacturer. For each biological replicate, qRTPCR reactions were carried out in triplicate (technical replicates) using $2 \mu \mathrm{L}$ Master Mix, $0.5 \mu \mathrm{L} 250 \mathrm{nM}$ each primer, $1 \mu \mathrm{L}$ diluted cDNA and nuclease-free water to a final volume of $20 \mu \mathrm{L}$. Controls (with no cDNA and RNA without RT) were included in each run. Fluorescence was measured at the end of each amplification cycle. Amplification was followed by a melting curve analysis with continual fluorescence data acquisition during the $65-95^{\circ} \mathrm{C}$ melt. The raw data were manually analyzed and expression was normalized to $S$. lycopersicum GAPDH gene (GAPDH, NCBI/GenBank Database accession number U97256) to minimize variation in cDNA template levels. For each gene, a standard curve was generated using a cDNA serial dilution, and the resultant PCR efficiency calculations were imported into relative expression data analysis. To ensure that the transcripts of single genes had been amplified, qRT-PCR amplicons were sequenced and confirmed as the expected plant DNA sequences. Primers used for each gene was, Lhcalf 5 -GAG GCA TTG GGC TTA GGT AAT TGG G-3' and qPCR-Lhca1r 5'-GCC CCA CCA GGA TAC TTC TTC-3'; ELIPf 5'-ATG GCT TCA CTC TCA TCT TC-3' and qPCR-ELIPr 5'-GAA GGA GGT CCT TTT GG-3'; PsbSf 5’ATG GCT CAA ACA ATG TTG TTA ACA-3' and qPCR-PsbSr 5'-CCT TTT TGG GAG GAG CTT TAG C-3'; GAPDHf 5 -ACA ACT TAA CGG CAA ATT GAC TGG-3' and GAPDHr 5 -TTA CCC TCT GAT TCC TCC TTG ATT G-3'.

\section{Experimental design and statistical analysis}

Data obtained were analyzed on the basis of a random design with three biological replicates for each treatment. Statistical analyses were performed using SigmaStat 3.1 (Systat Software, Inc. Richmond, California, USA). Differences between species and treatments were analyzed with two-way ANOVA and, where appropriate, with Tukey's test. Means were considered to be different $(P \leq 0.05)$. 


\section{RESULTS AND DISCUSSION}

Photosynthetic efficiency is more affected in $S$. lycopersicum than in S. chilense under high light and low temperature

The photosynthetic efficiency measured as photochemical yield of PSII (ФPSII) showed variations when $S$. lycopersicum and $S$. chilense were exposed to low temperature and high light (Figure 1), being higher in $S$. chilense (46\%) than in S. lycopersicum (27\%). Our results are in agreement with others studies (Rorat et al., 2001; Savitch et al., 2002; Hu et al., 2006) in which significant differences in $\Phi P S I I$ were related with different tolerance to photoinhibition.

Whilst $\Phi$ PSII are related to achieve efficiency, $\mathrm{qP}$ and $\mathrm{Fv} / \mathrm{Fm}$ provide information about underlying processes which have altered efficiency. A change in $\mathrm{qP}$ is due a closure of reaction centre, resulting from a saturation of photosynthesis by light. A change in Fv/Fm is due to a change in the efficiency of non-photochemical quenching (van Kooten and Snel, 1990). Photochemical quenching (qP) (Figure 2A) and photosynthetic electron transport (ETR) (Figure 2B) were significantly more affected in S. lycopersicum than S. chilense (Figure 2). On the other hand, neither Fv/Fm (Figure 2C) or NPQ (Figure 2D) were affected in both species. These results are in agreement with previous observations (Tapia, 2005; Hu et al., 2006) in which the depression in $\Phi$ PSII was driven primarily by $\mathrm{qP}$, not $\mathrm{Fv} / \mathrm{Fm}$, suggesting that the photo-oxidationinduced decline of ФPSII was due to down-regulation of processes such as C fixation (Hu et al., 2006). Thus, ours results gives an indication about the efficiency of S. chilense to use light for photochemistry. Interestingly, there are reports (Gray et al., 1994; Adams et al., 2001; Savitch et al., 2002) suggesting that tolerance of cereals to short-term photoinhibition (hours) are related to the maintenance of photosynthesis as the major quencher of excited chlorophyll.

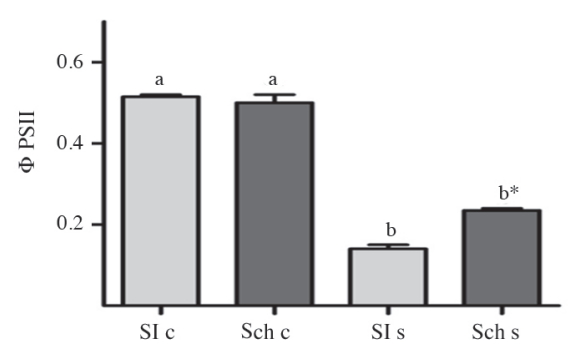

Data represent means \pm SE of three individual plants. Letters indicate differences according Tukey test $(P \leq 0.05)$ inside species in both conditions. Asterisks $(*)$ indicate significant differences between species under stress conditions. c: control condition; s: stress condition.

Figure 1. Changes in effective photochemical efficiency of photosystem II (ФPSII) in leaves of Solanum lycopersicum cv. Moneymaker (SI) and $S$. chilense $(\mathrm{Sch})$ under low temperature $\left(4^{\circ} \mathrm{C}\right)$ and high light $(1300 \mu \mathrm{mol}$ $\left.\mathrm{m}^{-2} \mathbf{s}^{-1}\right)$.
De-epoxidized xanthophylls are slightly higher in $S$. chilense than in S. lycopersicum under high light and low temperature

The increase in the content of de-epoxidized $(A+Z)$ may provide a better protection against photo-damage by increasing the capacity for xanthophyll cycle-related dissipation of excess energy in leaves exposed to high light and low temperature (Demmig-Adams and Adams, 1996). Ours results shown that in both species the conversion state of the xanthophyll cycle pool $(\mathrm{A}+\mathrm{Z}) /$ $(\mathrm{V}+\mathrm{A}+\mathrm{Z})$ increased along the stress treatment (Figure $3 \mathrm{~A}$ ) and the zeaxanthin formation was higher in S. chilense (44 mmol $\mu \mathrm{L}^{-1}$ ) than in S. lycopersicum $\left(26 \mathrm{mmol} \mu \mathrm{L}^{-}\right.$ $\left.{ }^{1}\right)$ (Figure 3B). In spite of this, the rather constant NPQ (Figure 2C) suggest that other mechanism, different to the thermal dissipation, are involved in the major tolerance of the photosynthetic apparatus of S. chilense to high light and low temperatures. Ours results are in accordance with a number of cases in which the accumulation of zeaxanthin was shown to increase tolerance to photo-oxidative stress protecting thylakoid membrane lipids from oxidative damage independently from NPQ (Lichtenthaler and Schnidler, 1992; Stefanov et al., 1996; Havaux and Niyogi, 1999; Havaux et al., 2004; Johnson et al., 2007).

\section{Lipid peroxidation is higher in S. lycopersicum than in S. chilense}

Since the oxidative breakdown of lipid molecules yields elevated levels of malondialdehyde, the MDA content is considered a useful index of general lipid peroxidation (Hodges et al., 1999; Møller et al., 2007). In control conditions, both species contained similar amount of

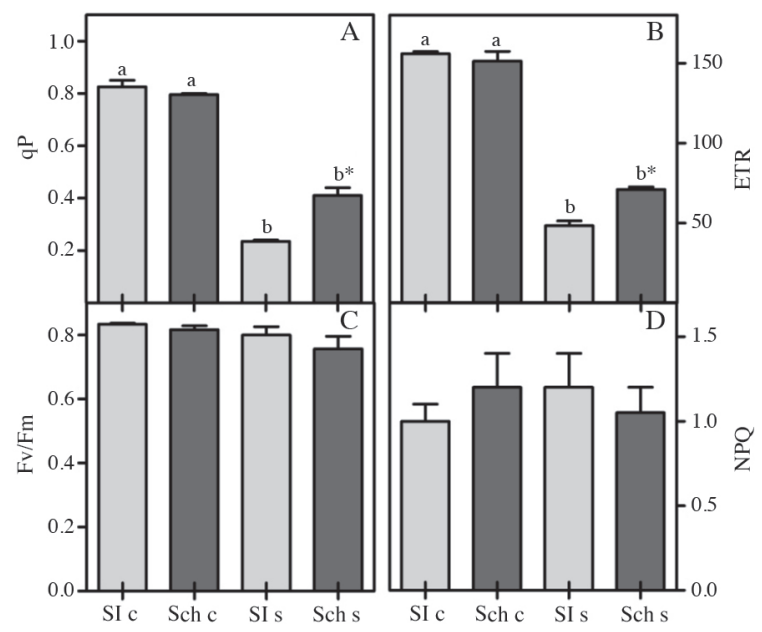

A) qP: photochemical quenching; B) ETR: electron transport rate; C) Fv/Fm: maximum quantum yield ; D) NPQ: non photochemical quenching. Data represents means $\pm \mathrm{SE}$ of three individual plants. Letters indicate differences according Tukey test $(P \leq 0.05)$ inside species in both conditions. Asterisks (*) indicate significant differences between species under stress conditions. c: control condition; s: stress condition.

Figure 2. Changes in fluorescence parameters in leaves of Solanum lycopersicum cv. Moneymaker (SI) and S. chilense (Sch) under low temperature $\left(4^{\circ} \mathrm{C}\right)$ and high light $\left(1300 \mu \mathrm{mol} \mathrm{m} \mathrm{m}^{-2} \mathrm{~s}^{-1}\right)$. 

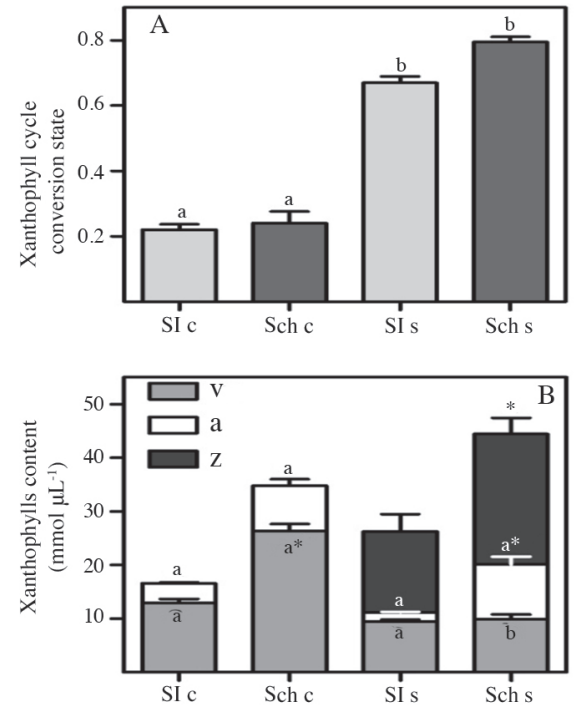

Changes in the xanthophyll cycle conversion state $(a+z) /(v+a+z)$; B) changes in content of violaxanthin (v), anteraxanthin (a) and zeaxanthin (z) (c: control condition; s: stress condition). Data represents means $\pm \mathrm{SE}$ of three individual plants. Letters indicate differences according Tukey test $(P \leq 0.05)$ inside species in both conditions. Asterisks $(*)$ indicate significant differences between species under stress conditions.

Figure 3. Xanthophyll variation in leaves of Solanum lycopersicum cv. Moneymaker $(\mathrm{SI})$ and $S$. chilense $(\mathrm{Sch})$ under low temperature $\left(4^{\circ} \mathrm{C}\right)$ and high light $\left(1300 \mu \mathrm{mol} \mathrm{m}^{-2} \mathrm{~s}^{-1}\right)$.

lipid peroxide (Figure 4), by contrast, the MDA content in leaves of S. lycopersicum was significantly higher than S. chilense during exposition to low temperature and high light treatment. Thus, $S$. chilense seems to be more tolerant to oxidative stress, as indicated by their low levels of lipid peroxide. These results are in agreement with reports that less MDA formation is related to some mechanism of oxidative stress tolerance (Shalata and Neumann, 2001; Hutin et al., 2003; Golan et al., 2006).

Expression of PsbS and Lhcal is higher in S. chilense than in $S$. lycopersicum under high light and low temperature

Isolated cDNAs for PsbS, Elip and Lhcal proved homologous in both species (data not shown). As a first approach to ascertain the role of this gene in S. chilense

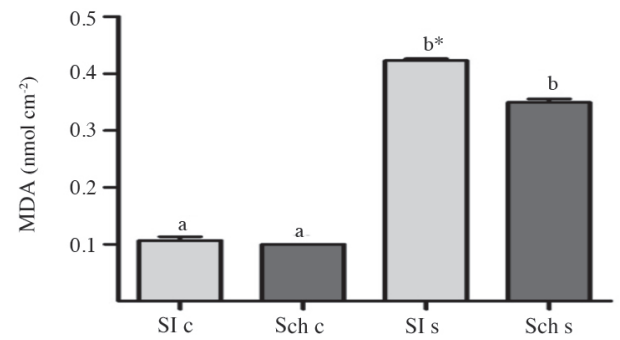

Data represents means $\pm \mathrm{SE}$ of three individual plants. Letters indicate differences according Tukey test $(P \leq 0.05)$ inside species in both conditions. Asterisks $(*)$ indicate significant differences between species under stress conditions. c: control condition; s: stress condition.

Figure 4. Malondialdehyde (MDA) variation in leaves of Solanum lycopersicum cv. Moneymaker (SI) and S. chilense (Sch) under low temperature $\left(4^{\circ} \mathrm{C}\right)$ and high light $\left(1300 \mu \mathrm{mol} \mathrm{m} \mathrm{m}^{-2} \mathrm{~s}^{-1}\right)$. plants exposed to low temperature and high light, its expression pattern was analyzed (Figure 5). qRT-PCR analysis of $P s b S$ showed an increase in transcript levels in S. chilense while no significative change was observed in S. lycopersicum (Figure 5A). This result could be consistent with others reports (Niyogi, 1999; Li et al., 2000), which suggest that plant tolerance to photooxidative stress induced by high light involve an increased NPQ capacity through adjustment of PsbS abundance. However, our results also showed that the mechanism of NPQ was not induced (Figure 2C), suggesting, as in Rorat et al. (2001) and Norén et al. (2003), that there is no increase in $P s b S$ translation at low temperature, and that post-transcriptional regulation plays a fundamental role in $P s b S$ expression. However as shown in Figure 3B, there is an increase in zeaxanthin content, accordingly there are reports that indicate that zeaxanthin could be bound by other members of the LHC family, the ELIP proteins (Havaux et al., 2004; Demmig-Adams et al., 2006; Johnson et al., 2007). ELIP protein has been associated with photoprotection in tolerant species (Montané et al., 1999; Adamska, 2000; Hutin et al., 2003). An increase in ELIP transcript levels in S. chilense was expected, however no significant differences between both species was observed upon low temperature and high light treatment (Figure 5B), suggesting, as in Hutin et al.

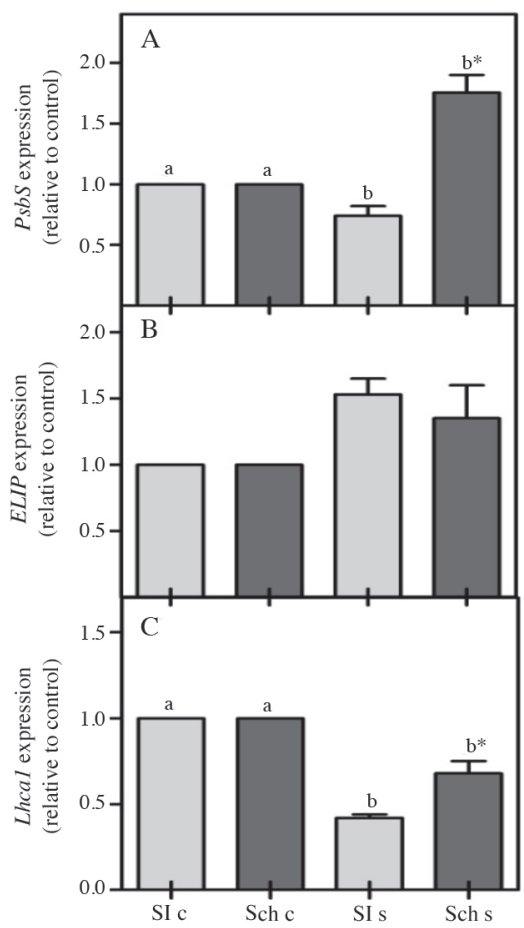

The expression levels of genes were normalized against that of SIGAPDH (c: control condition; $\mathrm{s}$ : stress condition). Data represents means $\pm \mathrm{SE}$ of three individual plants. Letters indicate differences according Tukey test $(P \leq 0.05)$ inside species in both conditions. Asterisks $(*)$ indicate significant differences between species under stress conditions.

Figure 5. Expression analysis of PsbS (A), ELIP (B) and Lhcal (C) in leaves of Solanum lycopersicum cv. Moneymaker (SI) and S. chilense (Sch) under low temperature $\left(4^{\circ} \mathrm{C}\right)$ and high light $\left(1300 \mu \mathrm{mol} \mathrm{m} \mathrm{m}^{-2} \mathrm{~s}^{-1}\right)$. 
(2003), that ELIP accumulation did not increase thermal energy dissipation (NPQ), but that it might be involved some antioxidative mechanism related to zeaxanthin. Because proteins for light harvesting are thought to have evolved from photoprotective ELIPs (Green, 2003), it seems logical to propose that the apparent ability of these proteins to prevent lipid peroxidation has been retained in the LHC proteins of both photosystems. It was believed that PSI was tolerant to environmental stresses, however was shown to be photoinhibited under chilling conditions and when the linear electron transport chain is unbalanced (Terashima et al., 1994; Sonoike and Terashima, 1994; Tjus et al., 1998; Ivanov et al., 1998; Scheller and Haldrup, 2005). PSI photoprotection has been suggested to be mainly mediated by oxygen scavenging enzymes (Asada, 1999), although recent evidences, suggested that PSI antenna proteins might play a relevant role in photoprotection against excess energy (Melkozernov and Blankenship, 2005; Alboresi et al., 2009), which could be regulated through carotenoids presents in the LHCI complex (Morosinotto et al., 2003). Taking that into account, we analyzed the transcript levels of the Lhcal gen, which encodes for one of the major polypeptide that form the antenna complex of PSI (Ben-Shem et al., 2004).

Although our results indicate that in both species there is a down-regulation of the Lhcal transcripts levels, it is important to point out that it remains higher in S. chilense than in S. lycopersicum (Figure 5C). Interestingly, there are reports that under certain conditions (e.g. high-light) there is a differential expression of LHCI genes (Bailey et al., 2001; Ensminger et al., 2004; Gáspár et al., 2006). On the other hand, Wehner et al. (2004) suggested that the zeaxanthin formed in LHCI proteins is involved in an antioxidative mechanism implicated in suppression of ROS-triggered lipid peroxidation rather than heat energy dissipation (NPQ), which could be consistent with our observations on the accumulation of zeaxanthin (Figure 3B) which can function as antioxidant, as evidenced by the amount of peroxidized lipids (Figure 4) and the invariable value of NPQ (Figure 2C).

\section{CONCLUSIONS}

The results presented here indicate that $S$. chilense showed higher tolerance to photoinhibition than S. lycopersicum under low-temperature and high light conditions, increasing light-energy consumption in photochemical processes by increasing photosynthetic capacity as indicate by $\mathrm{qP}$ and ETR parameters. The contribution of light-harvesting chlorophyll $\mathrm{a} / \mathrm{b}$ binding (LHC) protein was not related to dissipate excess excitation energy as heat (NPQ), but rather with the antioxidant function attributable to zeaxanthin as indicated by less MDA content in S. chilense. We suggest that the differential expression of Lhcal transcripts could contribute to the greater tolerance of $S$. chilense to photoxidative stress.

\section{ACKNOWLEDGEMENTS}

This work was supported by Universidad de Talca (DIATUtalca) and FIA (project BIOT-01-A-065). Javier Chilian acknowledges MECESUP for a doctoral scholarship.

Expresión de genes LHC y su relación con la tolerancia al estrés foto-oxidativo en Solanum lycopersicum L. y Solanum chilense (Dunal) Reiche. La exposición simultánea a las bajas temperaturas y alta intensidad lumínica causa la foto-inhibición del aparato fotosintético, fenómeno que afecta la productividad y la distribución geográfica de los cultivos. En varias especies de solanáceas, la tolerancia a este tipo de estrés se ha asociado con un cierto estímulo en el apagamiento no fotoquímico (NPQ), lo que implica una reorganización en las proteínas pertenecientes a los complejos colectores de luz (LHC). Para evaluar el rendimiento fotosintético de Solanum lycopersicum L. y S. chilense (Dunal) Reiche y evaluar la regulación transcripcional de genes que codifican para proteínas del LHC y su participación en el NPQ, plantas de ambas especies fueron expuestas a $4{ }^{\circ} \mathrm{C}$ y $1300 \mu \mathrm{mol}$ $\mathrm{m}^{-2} \mathrm{~s}^{-1}$ y se realizaron evaluaciones sobre la peroxidación lipídica, la eficiencia fotosintética y los cambios en los pigmentos del ciclo de las xantófilas. Al utilizar el exceso de energía de excitación en el proceso fotoquímico, según lo indicado por los parámetros qP y ETR, los resultados indican que $S$. chilense posee una mayor tolerancia a la foto-inhibición que S. lycopersicum. La contribución de las proteínas LHC no estaría relacionada con disipar el exceso de energía en forma de calor (NPQ), sino más bien con la función antioxidante atribuida a la zeaxantina, como se indica por la cantidad de lípidos peroxidados observados en $S$. chilense. Se sugiere que la expresión diferencial de los transcritos Lhcal, con sitios de unión para zeaxantina, podría contribuir a la mayor tolerancia al estrés foto-oxidativo por parte de $S$. chilense.

Palabras clave: Fotoinhibición, apagamiento fotoquímico, zeaxantina, lipoperoxidación.

\section{LITERATURE CITED}

Adams, W.W. III, B. Demmig-Adams, T.N. Rosenstiel, and V. Ebbert. 2001. Dependence of photosynthesis and energy dissipation activity upon growth form and light environment during the winter. Photosynthesis Research 76:51-62.

Adamska, I. 2000. The elip family of stress proteins in the thylakoid membranes of pro- and eukaryota. p. 487-505. In Eva-Mari Aro and Bertil Andersson (eds.) Regulatory aspects of photosynthesis. Kluwer Academic Publishers, Boston, London.

Alboresi, A., M. Ballottari, R. Hienerwadel, G. Giacometti, and T. Morosinotto. 2009. Antenna complexes protect Photosystem I from Photoinhibition. BMC Plant Biology 9:71.

Allen, D.J., and D.R. Ort. 2001. Impacts of chilling temperatures on photosynthesis in warm-climate plants. Trends in Plant Science 6:36-42.

Andersson, U., M. Heddad, and I. Adamska. 2003. Light stressinduced one-helix protein of the chlorophyll a/b-binding family 
associated with photosystem I. Plant Physiology 132:811-820.

Asada, K. 1999. The water-water cycle in chloroplasts: Scavenging of active oxygen and dissipation of excess photons. Annual Review Plant Physiology Plant Molecular Biology 50:601-639.

Bailey, S., R.G. Walters, S. Jansson, and P. Horton. 2001. Acclimation of Arabidopsis thaliana to the light environment: the existence of separate low light and high light responses. Planta 213:794-801.

Ben-Shem, A., F. Frolow, and N. Nelson. 2004. Light-harvesting features revealed by the structure of plant Photosystem I. Photosynthesis Research 81:239-250.

BioEdit. 2010. Alignment and ID search. Available at http://www. mbio.ncsu.edu/bioedit/bioedit.html (accessed October 2010).

Demmig-Adams, B., and W.W.Adams. 1996. The role of xanthophyll cycle carotenoides in the protection of photosynthesis. Trends in Plant Science 1:21-26.

Demmig-Adams, B., V. Ebbert, D.L. Mellman, K.E. Mueh, L. Schaffer, C. Funk, et al. 2006. Modulation of PsbS and flexible vs. sustained energy dissipation by light environment in different species. Physiologia Plantarum 127:670-680.

Ensminger, I., D. Sveshnikov, D.A. Campbell, C. Funk, S. Jansson, and J. Lloyd. 2004. Intermittent low temperatures constrain spring recovery of photosynthesis in boreal Scots pine forests. Global Change Biology 10:995-1008.

Foyer, C. 2002. The contribution of photosynthetic oxygen metabolism to oxidative stress in plants. p. 33-68. In Dirk Inzé and Marc Van Montagu (eds.) Oxidative stress in plants. Taylor and Francis Publishers, New York, USA.

Gáspár, L., E. Sárvári, F. Morales, and Z. Szigeti. 2006. Presence of "PSI free" LHCI and monomeric LHCII and subsequent effects on fluorescence characteristics in lincomycin treated maize. Planta 223:1047-1057.

Genty, B., J.M. Braintais, and N.R. Baker. 1989. The relationship between the quantum yield of photosynthetic electron transport and quenching of chlorophyll fluorescence. Biochimica and Biophysica Acta 990:87-92.

Gilmore, A.M., and H.Y. Yamamoto. 1991. Resolution of lutein and zeaxanthin using a non-endcapped, lightly carbon-loaded $\mathrm{C}_{18}$ high-performance liquid chromatographic column. Journal of Chromatography 534:137-145.

Golan, T., P. Müller-Moule, and K.K. Niyogi. 2006. Photoprotection mutants of Arabidopsis thaliana acclimate to high light by increasing photosynthesis and specific antioxidants. Plant Cell and Environment 29:879-887.

Gray, G.R., S.R. Boese, and N.P.A. Huner. 1994. A comparison of low temperature growth vs. low temperature shift to induce resistance to photoinhibition in spinach (Spinacia oleracea). Plant Physiology 90:560-566.

Green, B.R. 2003. The evolution of light-harvesting antennas. p. 129-168. In Beverly R. Green, and William W. Parsons (eds.) Light-harvesting antennas in photosynthesis. Kluwer Academic Publishers, Dordrecht, The Netherlands.

Havaux, M., L. Dall'Osto, S. Cuiné, G. Giuliano, and R. Bassi. 2004. The effect of zeaxanthin as the only xanthophyll on the structure and function of the photosynthetic apparatus in Arabidopsis thaliana. The Journal of Biological Chemistry 279:13878-13888.

Havaux, M.Y., and K.K. Niyogi. 1999. The violaxantin cycle protects plants from photooxidative damage by more than one mechanism. Proceedings of the National Academy of Sciences of the United States of America 96:8762-8767.

Hodges, D.M., J.M. DeLong, C.F. Forney, and R.K. Prange. 1999. Improving the thiobarbituric acid-reactive substance assay for estimating lipid peroxidation in plant tissues containing anthocyanin and other interfering compounds. Planta 207:604611.

Holt, N.E., G.R. Fleming, and K.K. Niyogi. 2004. Toward an understanding of the mechanism of nonphotochemical quenching in green plants. Biochemistry 43:8281-8289.

Horton, P., A. Ruban, and R.G. Walts. 1994. Regulation of light harvesting in green plants indication by non-photochemical quenching of chlorophyll fluorescence. Physiologia Plantarum 106:415-420.
Hu, W.H., Y.H. Zhou, Y.S. Du, X.J. Xia, and J.Q. Yu. 2006. Differential response of photosynthesis in greenhouse- and fieldecotypes of tomato to long-term chilling under low light. Journal of Plant Physiology 163:1238-1246.

Hutin, C., L. Nussaume, N. Moise, I. Moya, K. Kloppstech, and M. Havaux. 2003. Early light-induced proteins protect Arabidopsis from photooxidative stress. Proceedings of the National Academy of Sciences of the United States of America 100:4921-4926.

Ivanov, A.G., R.M. Morgan, G.R. Gray, M.Y. Velitchkova, and N.P.A. Huner. 1998. Temperature/light dependent development of selective resistance to photoinhibition of photosystem I. FEBS Letters, 430:288-292.

Johnson, M.P., M. Havaux, C. Triantaphylidès, B. Ksas, A.A. Pascal, B. Robert, et al. 2007. Elevated zeaxanthin bound to oligomeric LHCII enhances the resistance of Arabidopsis to photooxidative stress by a lipid-protective, antioxidant mechanism. Journal of Biological Chemistry 282:22605-22618.

Karpinski, S., G. Wingsle, B. Karpinska, and J. Hallgren. 2002. Low-temperature stress and antioxidant defense mechanisms in higher plants. p. 69-104. In Dirk Inzé, and Marc Van Montagu (eds.) Oxidative stress in plants. Taylor and Francis Publishers, New York, USA.

Ledford, H.K., and K.K. Niyogi. 2005. Singlet oxygen and photooxidative stress management in plants and algae. Plant, Cell \& Environment 28:1037-1045.

Li, X.P., O. Bjorkman, C. Shih, A.R. Grossman, M. Rosenquist, S. Jansson, and K. Niyogi. 2000. A pigment-binding protein essential for regulation of photosynthetic light harvesting. Nature 403:391-395.

Lichtenthaler, H.K., and C. Schnidler. 1992. Studies on the photoprotective function of zeaxanthin at high light conditions. p. 517-524. In Murata, N. (ed.) Research in photosynthesis. Kluwer Academic Publishers, Dordrecht, The Netherlands.

Long, S.P., S. Humphries, and P.G. Falkowski. 1994. Photoinhibition of photosynthesis in nature. Annual Review of Plant Physiology and Plant Molecular Biology 45:633-662.

Maldonado, C., F. Squeo, and E. Ibacache. 2003. Respuesta fenotípica de Lycopersicon chilense al déficit hídrico. Revista Chilena de Historia Natural 76:129-137.

Melkozernov, A.N., and R.E. Blankenship. 2005. Structural and functional organization of the peripheral light-harvesting system in Photosystem I. Photosynthesis Research 85:33-50.

Mittler, R., S. Vanderauwera, M. Gollery, and F. Van Breusegem. 2004. Reactive oxygen gene network of plants. Trends in Plant Science 9:490-498.

Møller, I.M., P.E. Jensen, and A. Hansson. 2007. Oxidative modifications to cellular components in plants. Annual Review of Plant Biology 58:459-481.

Montané, M.H., and K. Kloppstech. 2000. The family of lightharvesting-related proteins (LHCs, ELIPs, HLIPs): was the harvesting of light their primary functions? Gene 258:1-8.

Montané, M.H., B. Petzold, and K. Kloppstech. 1999. Formation of early-light-inducible-protein complexes and status of xanthophyll levels under high light and cold stress in barley (Hordeum vulgare L.) Planta 208:519-527.

Morosinotto, T., S. Caffarri, L. Dall'Osto, and R. Bassi. 2003. Mechanistic aspects of the xanthophyll dynamics in higher plant thylakoids. Physiologia Plantarum 119:347-354.

Morosinotto, T., S. Castelletti, J. Breton, R. Bassi, and R. Croce. 2002. Mutation analysis of Lhca1 antenna complex: Low energy absorption forms originate from pigment-pigment interactions. Journal of Biological Chemistry 277:36253-36261.

Muller, P., X.P. Li, and K.K. Niyogi. 2001. Non-photochemical quenching. A response to excess light energy. Plant Physiology 125:1558-1566.

Murashige, T., and F. Skoog. 1962. A revised medium for rapid growth and bioassays with tobacco tissue cultures. Physiologia Plantarum 15:473-497.

National Center for Biotechnology Information. 2010. BLAST finds regions of similarity between biological sequences. Available at http://www.ncbi.nlm.nih.gov/ (accessed October 2010). 
Nelson, N., and Ch.F. Yocum. 2006. Structure and function of photosystems I and II. Annual Review of Plant Biology 57:521565 .

Niyogi, K.K. 1999. Photoprotection revisited: Genetic and molecular approaches. Annual Review of Plant Physiology and Plant Molecular Biology 50:333-359.

Norén, H., P. Svensson, R. Stegmark, C. Funk, I. Adamska, and B. Anderson. 2003. Expression of the early light-induced protein but not the PsbS protein is influenced by low temperature and depends on the developmental stage of the plant in field-grown pea cultivars. Plant, Cell and Environment 26:245-253.

Rorat, T., M. Havaux, W. Irzykowski, S. Cuiné, N. Becuwe, and P. Rey. 2001. PSII-S gene expression, photosynthetic activity and abundance of plastid thioredoxin-related and lipid-associated proteins during chilling stress in Solanum species differing in freezing resistance. Physiologia Plantarum 113:72-78.

Savitch, L.V., E.D. Leonardos, M. Krol, S. Jansson, B. Grodzinski, N.P.A. Huner, and G. Öquist. 2002. Two different strategies for light utilization in photosynthesis in relation to growth and cold acclimation. Plant, Cell and Environment 25:761-771.

Scheller, H.V., and A. Haldrup. 2005. Photoinhibition of photosystem I. Planta 221:5-8.

Shalata, A., and P.N. Neumann. 2001. Exogenous ascorbic acid (vitamin C) increases resistance to salt stress and reduces lipid peroxidation. Journal Experimental Botany 52:2207-2211.

Sonoike, K., and I. Terashima. 1994. Mechanism of photosystem-I photoinhibition in leaves of Cucumis-sativus L. Planta 194:287293.

Stefanov, D., I. Yordanov, and T. Tsonev. 1996. Effect of thermal stress combined with different irradiance on some photosynthetic characteristics on barley (Hordeum vulgare L.) plants. Photosynthetica 32:171-181.
Tapia, G.M. 2005. Estudio de los procesos fotosintéticos, del metabolismo de azúcares y la expresión génica durante la aclimatación a estrés salino y sequía en Lycopersicon chilense. Tesis Doctorado Instituto de Biología Vegetal y Biotecnología. Universidad de Talca, Talca, Chile.

Terashima, I., S. Funayama, and K. Sonoike. 1994. The site of photoinhibition in leaves of Cucumis-sativus L. at lowtemperatures is photosystem- I, not photosystem-II. Planta 193:300-306

Tjus S.E., B.L. Moller, and H.V. Scheller. 1998. Photosystem I is an early target of photoinhibition in barley illuminated at chilling temperatures. Plant Physiology 116:755-764.

van Kooten, O., and J.H.F. Snel. 1990. The use of chlorophyll fluorescence nomenclature in plant stress physiology. Photosynthesis Research 25:147-150.

Venema, J.H., P. Linger, A.W. van Heusden, P.R. van Hasselt, and W. Brüggemann. 2005. The inheritance of chilling tolerance in tomato (Lycopersicon spp.) Plant Biology 7:118-130.

Venema, J.H., F. Posthumus, M. De Vries, and P.R. Van Hasselt. 1999 Differential response of domestic and wild Lycopersicon species to chilling under low light: carbohydrate content, photosynthesis and the xanthophyll cycle. Physiologia Plantarum 105:81-88.

Wehner, A., S. Storf, P. Jahns, and V. Schmid. 2004. De-epoxidation of violaxanthin in light-harvesting complex I proteins. Journal of Biological Chemistry 279:26823-26829.

Yamamoto, H.Y. 1979. Biochemistry of violaxanthin cycle in higher plants. Pure and Applied Chemistry 51:639-648.

Yáñez, M., S. Cáceres, S. Orellana, A. Bastías, I. Verdugo, S. RuizLara, and J.A. Casaretto. 2009. An abiotic stress-responsive bZIP transcription factor from wild and cultivated tomatoes regulates stress-related genes. Plant Cell Reports 28:1497-1507. 